\title{
Recorregut de recerca geològica i mineralògica per la comarca del Pallars Jussà: des de Basturs cap Abella de la Conca, a Bóixols i a Isona
}

Josep Maria Mata-Perelló

Joaquim Sanz Balagué

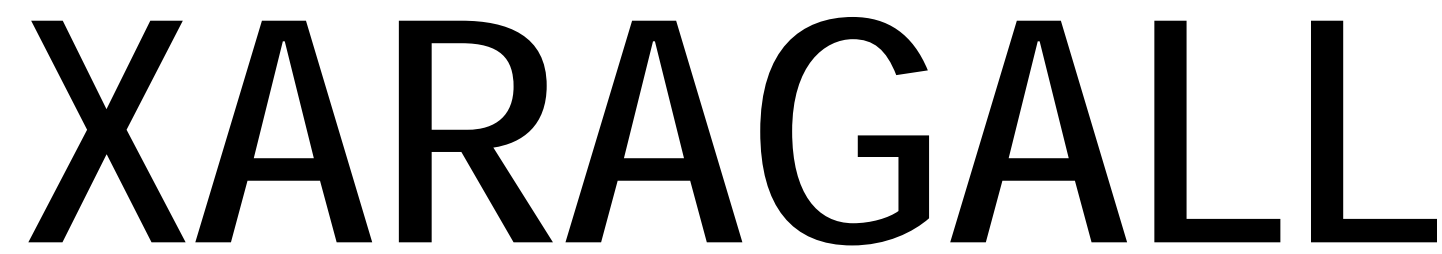

REVISTA DE CIÈNCIES DE LA CATALUNYA CENTRAL

n. 8

AGOST 2014 


\section{RECORREGUT DE RECERCA GEOLÒGICA I MINERALÒGICA PER LA COMARCA DEL PALLARS JUSSÀ: DES DE BASTURS CAP ABELLA DE LA CONCA, A BÓIXOLS I A ISONA}

\section{Josep Maria Mata-Perelló}

Museu de geologia Valentí Masachs, Escola Politècnica Superior d'Enginyeria de Manresa (EPSEM), Universitat Politècnica de Catalunya · BarcelonaTech (UPC), 08272 Manresa, Spain

\section{Joaquim Sanz Balagué}

Departament d'Enginyeria Minera i Recursos Naturals (EMRN), Escola Politècnica Superior d'Enginyeria de Manresa (EPSEM), Universitat Politècnica de Catalunya - BarcelonaTech (UPC), 08272 Manresa, Spain

Paraules clau: Sistema pirinenc; Patrimoni miner

\section{Resum}

Itinerari realitzat el 8 de setembre de 2013. En aquesta ocasió, el recorregut de l'itinerari discorrerà, en la seva quasi totalitat pel Sistema Pirinenc, i més concretament ho farà per la seva Unitat Sudpirinenca Central (també anomenada com a les Serres Exteriors Prepirinenques).

En concret, el recorregut del present itinerari passarà per dos dels seus sectors més representatius; concretament pel Mantell del Montsec (més situat al Sud) i també per alguns indrets del Mantell de Bóixols.

Així, l'itinerari s'iniciarà dintre del Mantell del Montsec (molt prop del seu contacte amb el Mantell de Bóixols). Després en bona part del recorregut, en transitarà per la zona de contacte entre els dos mantells anteriors. Més endavant, després travessar part del segon mantell, el recorregut tornarà a penetrar-se al Mantell del Montsec, per on finalitzarà el recorregut de l'itinerari.

Per altra banda, el recorregut de l'itinerari discorrerà íntegrament per una sola comarca: per la del Pallars Jussà (de la Regió de Tremp). 


\section{Objectius fonamentals}

Es centraran en els aspectes geològics, geomorfològics i mineralògics que apuntarem a continuació:

1. Estudi de l'estructura materials dels relleus prepirinencs de la Unitat Sud-pirinenca Central, que es tallaran al llarg del recorregut de tot l'itinerari, entre Basturs, Abella de la Conca, Bóixols i les immediacions d'Isona. Aquests relleus, es distribuiran entre el Mantell de Bóixols i el Mantell de Montsec.

2. Estudi i observació dels materials mesozoics (del Juràssic i sobretot del Cretàcic), i del cenozoic (fonamentalment de l'Eocè i de l'Oligocè), que formen part dels relleus dels mantells acabats d'esmentar al paràgraf anterior. I, tanmateix dels materials oligocènics postorogènics que ocasionalment els cobreixen.

3. Observació de les relacions existents, dintre de la zona per la qual discorre el recorregut de l'itinerari, entre les zones abans esmentades, del Sistema Pirinenc. (concretament entre el Mantell de Bóixols i del Mantell del Montsec).

4. Observació de l'important jaciment fossilífer dels ous de dinosaures, situat prop de Basturs, entre els sediments cretàcics.

5. Reconeixement de diverses mineralitzacions situades al llarg del recorregut del present itinerari, com les següents, d'acord amb el sentit de la marxa, tot i que en general seran poc importants.

6. Observació dels diferents indrets relacionats amb el patrimoni geològic que anirem trobant al llarg del recorregut d'aquest itinerari. En concret, d'acord amb el sentit de la marxa, cal parlar de:

6a) de l'important jaciment fossilífer de Basturs, caracteritzat per la presència d'ous de dinosaures

6b) dels coneguts Estanys de Basturs, molt afectat els darrers anys per l'extracció d'aigües il-legal, per tal de pal-liar la sequera

6c) del congost d'Abella de la Conca, directament relacionat amb l'encavalcament de l'Abella

6d) de l'encavalcament de Bóixols, molt similar al que haurem vist a Abella de la Conca.

6e) del jaciment d’icnites de la Mare de Deu de la Posa, que veurem en la darrera aturada del recorregut de l'itinerari.

7. Observació dels diferents indrets relacionats amb el patrimoni miner, si s'escau, que anem trobant al llarg del recorregut d'aquest itinerari. 


\section{Antecedents}

En relació amb aquest itinerari geològico-mineralògic, existeixen diversos antecedents nostres: Mata-Perelló (1995, 1996a, 1996b, 1996c, 1996d, 1999, 2002a, 2002b, 2009 i del recent 2013); així com de Mata-Perelló i Montané $(2002,2005 a, 2005 b$ i 2006). Es tracta, en tots els casos, d'itineraris similars al que ara tractarem, i que discorren per aquestes mateixes comarques en la seva major part del recorregut.

Pel que fa a les mineralitzacions que veurem en aquest itinerari, cal dir que també ja estat prèviament descrites per nosaltres mateixos en Mata-Perelló (1991). En aquest treball es fa referència a les mineralitzacions catalanes en general, parlant-se també de les situades al llarg d'aquest itinerari; i que es distribueixen tant per la Noguera, com pel Pallars Jussà.

I pel que fa a l'estructura geològica, ens remetérem a Riba et altri (1976), i a Guimerà et altri (1992). En ambdós treballs, es fa referència a l'estructura geològica dels Països Catalans. Per d'altra banda, també ens cal fer referència de Rosell (1970); així com de l'IGME (1994).

Finalment, cal dir que tots aquests treballs, es trobaran relacionats, per estricte ordre alfabètic, dintre de l'apartat dedicat a les REFERĖNCIES BIBLIOGRÀFIQUES, al qual es remetem, pel que s'escaigui.

\section{Recorregut de l'itinerari}

Aquest itinerari, s'iniciarà per les immediacions de la petita població de Basturs, on s' haurà arribat des de Figuerola d'Orcau, tot seguint la carretera local LV - 5113. Prop de Basturs s'efectuaran dues aturades: una als jaciments d'ous de dinosaures i una altra als estanys de Basturs. Totes dues molt properes a la població.

Posteriorment, el recorregut es dirigirà cap a Sant Romà d'Abella, per tal d'anar després cap al poble d'Abella de la Conca, per on es farà una nova aturada. Tot seguit, des d'aquest poblet, s'anirà per una pista forestal (en bones condicions) cap a la Collada de Carrànina, des d'on es baixarà cap a Bóixols. En aquest recorregut es faran diverses aturades.

Tot seguit, des d'aquest darrer poble, s'anirà cap a Isona, tot seguint la carretera local $L-511$. Abans d'arribar-hi, es farà una fillola, per tal d'anar cap al Jaciment d'Icnites de la Mare de Deu de la Posa, per on es farà una nova aturada. Finalment, després de retornat a la carretera $L-511$, s'anirà finalment cap a Isona. En arribar a aquesta darrera població, finalitzarà el recorregut d'aquest itinerari, després de retornar a la carretera autonòmica C - 1412c. 


\section{Advertiments previs}

Com en altres recorreguts de RECERCA GEOLÒGICA I MINERALÒGICA ..., si es disposa del temps suficient, poden efectuar-se passant per totes les parades i filloles. En cas contrari, recomanem prescindir de les anomenades PARADES - CONDICIONALS.

Per d'altra banda, cal tenir cura del coneixement de l'estat de conservació d'alguns dels trams dels camins a recórrer. En concret, del que ens ha de conduir des del poble de Basturs al jaciment d'ous de dinosaures. També és el cas del camí que ens conduirà des d'Abella cap a les immediacions de Bóixols.

Per d'altra banda, i a l'igual que en altres recorreguts semblants, recomanem tenir el màxim de cura i de respecte, entorn de la Natura que ens rodeja.

\section{Descripció de l'itinerari}

Com ja és habitual, farem una sèrie de PARADES (o de ESTACIONS). En cada una d'elles, farem esment del terme municipal on es troben (en el cas de que no quedi clar, al situar la parada), així com del número del MAPA TOPOGRÁFICO NACIONAL (a escala 1:50.000), que indicarem entre parèntesi.

Per d'altra banda, en cada una de les parades indicarem el nom del municipi, en el qual es troben situades. També indicarem el nombre de la comarca en el qual es troba situada. En aquesta ocasió, utilitzarem els dos següents fulls: 252 (Tremp) i 253 (o d'Organyà). Tots aquests fulls, han estat publicats per Instituto Geogràfico y Catastral de España.

Així doncs, la relació general ordenada de les aturades que composen aquest itinerari, es el següent:

\subsection{Parada 1. JACIMENT D'OUS DE DINOSAURES DE BASTURS DEL BARRANC DE COSTA GRAN, (Basturs, terme municipal d'Isona i la Conca Dellà, comarca del Pallars Jussà). (Full 252).}

Tot i que haurem iniciat el recorregut a Figuerola d'Orcau (sobre la carretera $C-1412 c$ ), ens caldrà agafar la carretera local LV - 5113, per tal d'anar cap al poble de Basturs. Aquí, en arribar a la plaça, cal seguir pel camí de l'esquerra dels dos que parteixen en direcció nord, seguint aquest camí fins que aquest talla el rierol del barranc de la Costa Grau. Aquí cal deixar els cotxes, per tal de continuar caminant fins trobar-nos amb uns materials de color vermell que cabussen fortament vers el sud constituint d'indret anomenat Costa dels Corrals. Aquí es farà una nova aturada, a uns $7 \mathrm{Km}$ de la parada anteriorment realitzada.

En aquest recorregut, hem anat trobant afloraments dels materials cretàcics que pertanyen al Garumnià, els quals troben a l'extrem septentrional del Mantell del Montsec. Aquests materials es troben al límit del Cretàcic al Paleocè, tot i que a l'indret de l'aturada pertanyen al Maestrichtià.

Precisament, en aquest indret, afloren aquests materials, molt sorrencs, de tonalitats rogenques. Dintre d'aquests materials es poden veure unes partícules allargades de color gris clar / blanc que contrasten amb el vermell de la resta de components d'aquest gres. Si ens mirem en detall aquestes partícules blanques allargassades apreciarem com un del seus marges és llis mentre que l'altre és granellut i com tota la partícula està solcada, 
perpendicularment a aquests marges més llargs, per porus. Aquestes partícules no són res mes que fragments de closques d'ous de dinosaure; si resseguim un xic aquest aflorament ens trobarem amb porcions grans de closca, ous més o menys sencers i potser algun niu. Cal notar com la mida i el número de porus apreciables en aquests fragments d'ou són elevats.

De ben segur que la particularitat què més ens crida l'atenció d'aquest jaciment és la gran quantitat d'ous que hi ha i el fet de que tots siguin iguals, possiblement pertanyen a una única espècie encara desconeguda doncs, en cara no s'ha trobat cap os de dinosaure en aquest jaciment ni cap ou amb l'embrió en l'interior.

Amb totes aquestes dades podem fer una interpretació de la història d'aquesta platja de les acaballes del Mesozoic. Tots els ous que hi ha en aquesta platja semblen ser de la mateixa espècie, això i la gran quantitat que n'hi ha ens porta a pensar que es tracta d'un lloc de nidificació, una colònia on uns grans dinosaures acudien per procurar la seva descendència. Aquesta colònia de nidificació estava constituïda per individus sans. Podem fer aquesta afirmació mercès a la absència de restes esquelètiques. De la mateixa manera podem intuir que aquí no hi havia depredació.

Un tipus de cranc es veia beneficiat per l'afluència de dinosaures. La gran quantitat de matèria orgànica aportada a aquesta platja en eclosionar o no els ous de dinosaure possiblement representava un massiu increment temporal de nutrients, aquest era aprofitat per una gran munió d'artròpodes, els autors dels burrows apreciables en el material.

Aquest jaciment de restes de dinosaure, conjuntament amb la resta que tenim en aquesta zona, a Coll de Nargó, Camarasa i altres localitats pirinenques, són un dels tres llocs existents en el planeta on es pot estudiar el trànsit entre el Mesozoic i el Cenozoic. (fotografia 1).

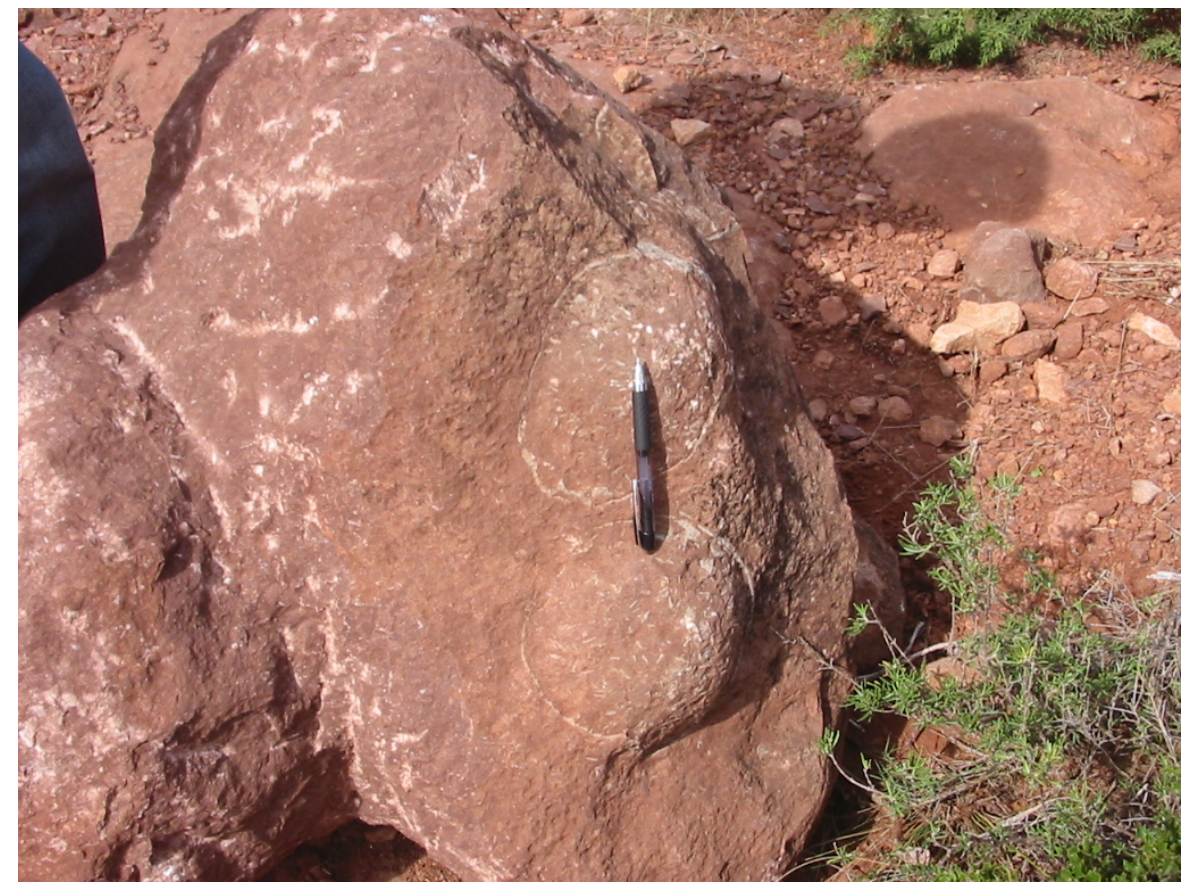

Fotografia 1. Una mostra dels restes dels ous de dinosaure. Febrer 1997 


\subsection{Parada 2. ESTANYS DE BASTURS, (Basturs, terme municipal d'Isona i la Conca Dellà, comarca del Pallars Jussà). (Full 252).}

Després de fer l'aturada anterior, ens caldrà retornar cap a Basturs, per tal d'agafar un altre camí que es dirigeix cap a l'indret on hi ha estanys de Basturs, on farem la present aturada, a uns $3 \mathrm{Km}$ de la parada anterior.

En aquest recorregut, hem trobat afloraments dels materials cretàcics, que ja hem esmentat a les aturades anteriors. Com en aquell cas, estem a l'extrem septentrional del Mantell del Montsec

Es tracta de dos llacs kàrstics de característiques similars als també pirinencs t'Estanya (a la comarca de la Ribagorça Oriental) i al de Montcortès (el qual es troba al Pallars Sobirà). La formació d'aquests llacs respon al model de col-lapse d'una cavitat kàrstica, tot formant-se una dolina que resta plena d'aigua per trobar-se en la mateixa cota que el nivell freàtic. La principal diferència entre aquests llacs i els altres citats és els materials sobre els quals es troben, en aquest cas són calcarenites i calcàries de les fàcies garumnianes que formen part del Sinclinal de Tremp i per tant no situades sobre fronts d'encavalcament (materials triàsics) com és el cas dels esmentats llacs d'Estanya i del llac de Montcortès.

Mereix especial menció la importància dels estanys de Basturs des del punt de vista biològic $\mathrm{i}$ l'alt grau de degradació i contaminació que pateixen per efecte de l'activitat agrícola i ramadera. Aquests llacs que han estat amenaçats per accions antròpiques (contaminacions, explotació de les seves aigües,...) formen part del nostre Patrimoni Geològic; així com del Patrimoni Natural i cal protegir-los davant de qualsevol acció contra ells i el seu entorn. (fotografies 2 i 3). En aquesta fotografia es mostra un dels estanys mig assecat, afortunadament (a la 2), més endavant s'ha anat recuperant (a la 3).

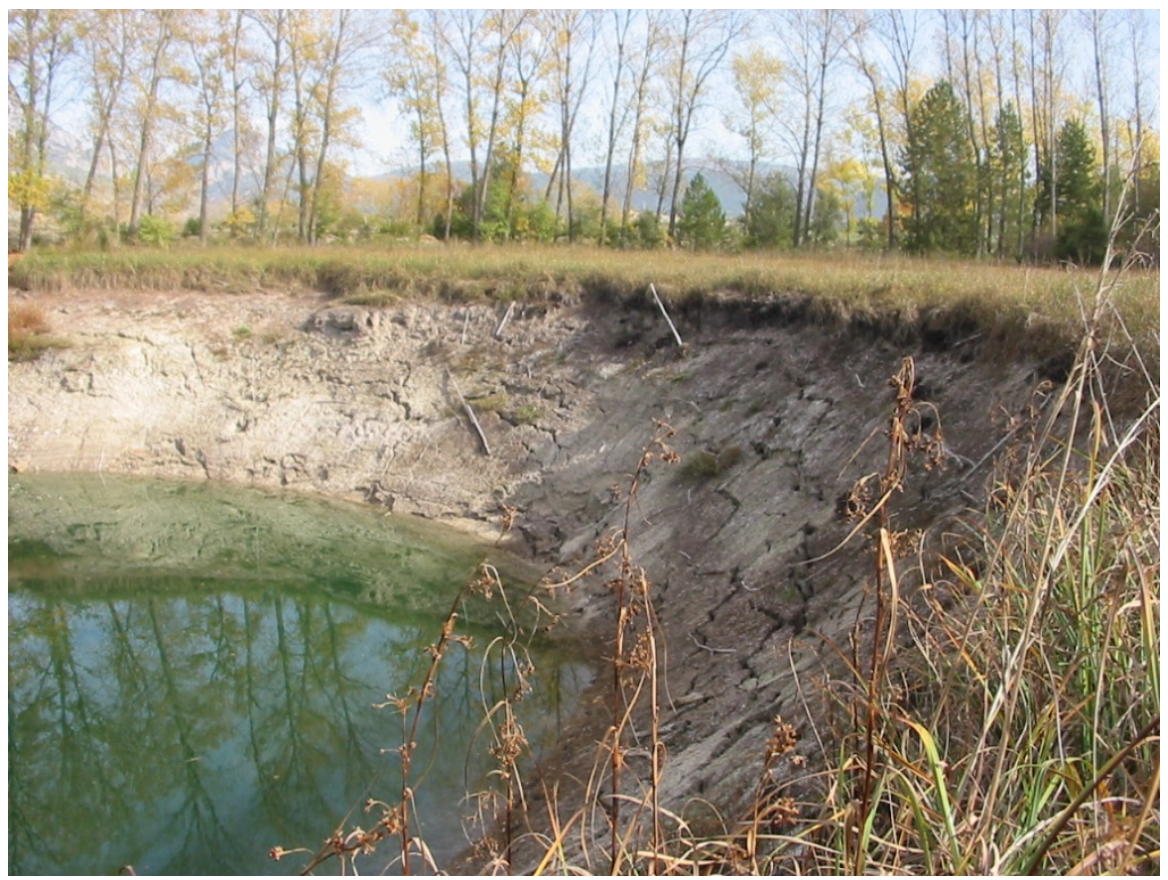

Fotografia 2. Un dels estanys, mig dessecat (tardor del 2005, octubre) 


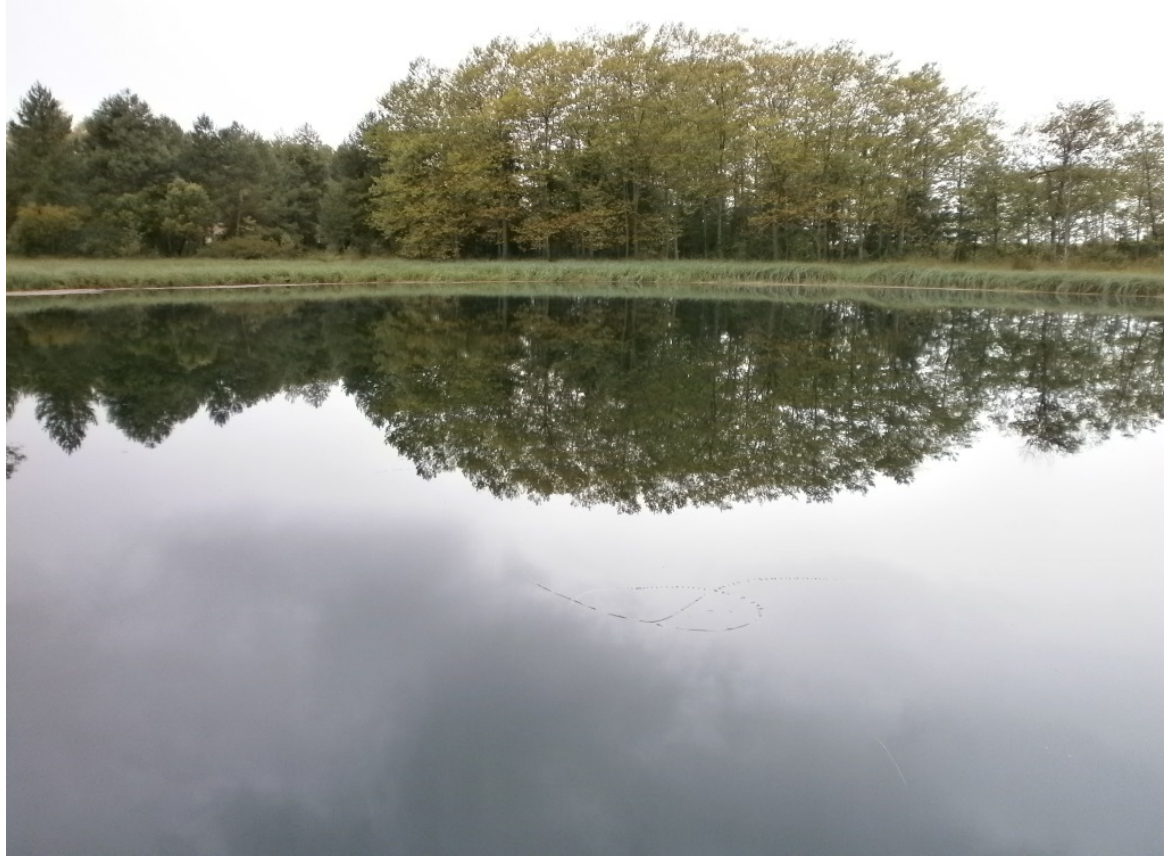

Fotografia 3. El mateix estany, ple (setembre del 2013)

Per d'altra banda, prop d'aquest indret, a l'esquerra dels estanys i de la carretera que condueix cap a Sant Romà d'Abella, es pot veure fàcilment una dolina.

\subsection{Parada 3. ENTRADA AL POBLE d’ABELLA DE LA CONCA, (Abella de la Conca, terme municipal d'Abella de la Conca, comarca del Pallars Jussà). (Full 252).}

Després de fer la parada anterior, cal seguir cap al proper poble de Sant Romà d'Abella. En arribar al poble, ens cal agafar el camí d'Abella de la Conca. En arribar-hi farem una nova aturada, després de recórrer uns $7 \mathrm{Km}$ des de la parada anterior.

En aquest recorregut, hem anat tallant els materials esmentats a la parada anterior. Per d'altra banda, des de bona part del recorregut, hem pogut veure des de lluny l'impressionant encavalcament d'Abella, corresponent al Mantell de Bóixols sobre el Mantell del Montsec. Ara, en arribar al poble, el podem veure des de ben a prop.

També, des d'aquí es pot veure el congost que forma el riu Abella en travessar les calcàries cretàciques, que formen part de l'esmentat encavalcament. Així, des d'aquí podem veure el Congost d'Abella de la Conca. Aquest congost, denominat lo Forat d'Abella (i popularment lo Foradot), ha estat obert per aquest riu, en travessar la Serra de Carrànima. De fet, hi ha tres congostos successius, originats pel riu en trobar-se els diferents fronts d'encavalcament del Mantell de Bóixols sobre l'extrem septentrional del Mantell del Montsec. 
També podem veure el front d'encavalcament sobre les mateixes cases del poble. Aquest lloc on ara ens trobem és un interessant indret, el qual pot formar part del nostre Patrimoni Geològic. (fotografia 4).

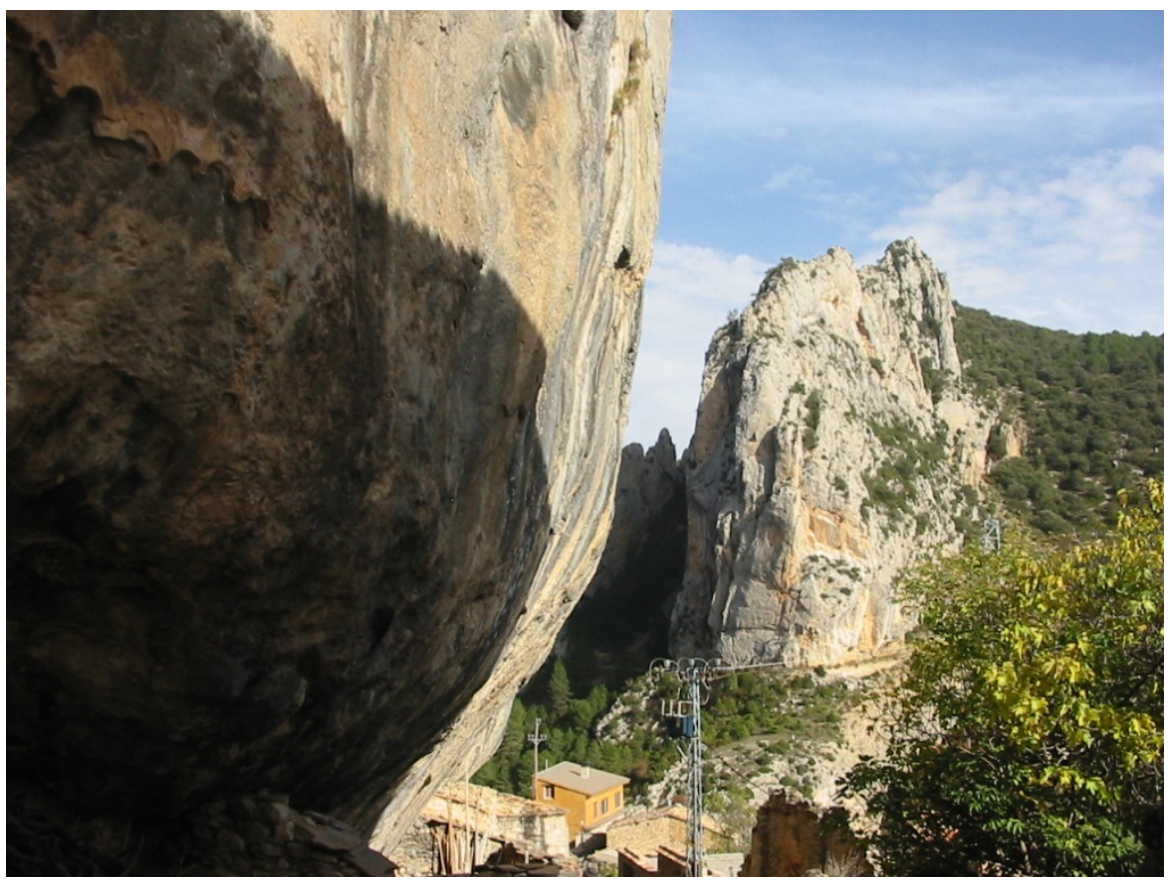

Fotografia 4. Un aspecte del front d'encavalcament del Mantell de Bóixols, amb el poble i el congost d’Abella de la Conca (lo Foradot), obert pel riu Abella.

\subsection{Parada 4. LO FORADOT, (Abella de la Conca, terme municipal d'Abella de la Conca, comarca del Pallars Jussà). (Full 252).}

Després de fer la parada anterior, cal retrocedir lleugerament, fins prop de la casa on hi ha I'Ajuntament d'Abella de la Conca, a uns 1'5 Km del poble. Així, trobarem una cruïlla, d'on surt una carretera asfaltada (que després es converteix en un camí). Aquest vial condueix cap al poble de Bóixols. Tot i així, va serpentejant i s'apropa molt al poble d'Abella de la Conca, just fins al altre cantó del congost del riu Abella. Aquí farem una nova aturada, a uns $4 \mathrm{Km}$ de I'anterior, però a tocar del poble.

En aquest recorregut, haurem tornat a trobar els afloraments dels materials del Garumnià, del Mantell del Montsec. Tot i això, ara ens tornem a trobar sobre afloraments dels materials carbonatats del Cretàcic Mig i de l'inferior, situant-nos dintre del Mantell de Bóixols i encavalcant als anteriors.

En aquest recorregut, haurem vis relleus espectaculars dels materials cretàcics, situats sobre el poble d'Abella de la Conca. (fotografia 5). Així, des d'aquí, es poden veure aquests materials, pràcticament verticalitzats. 


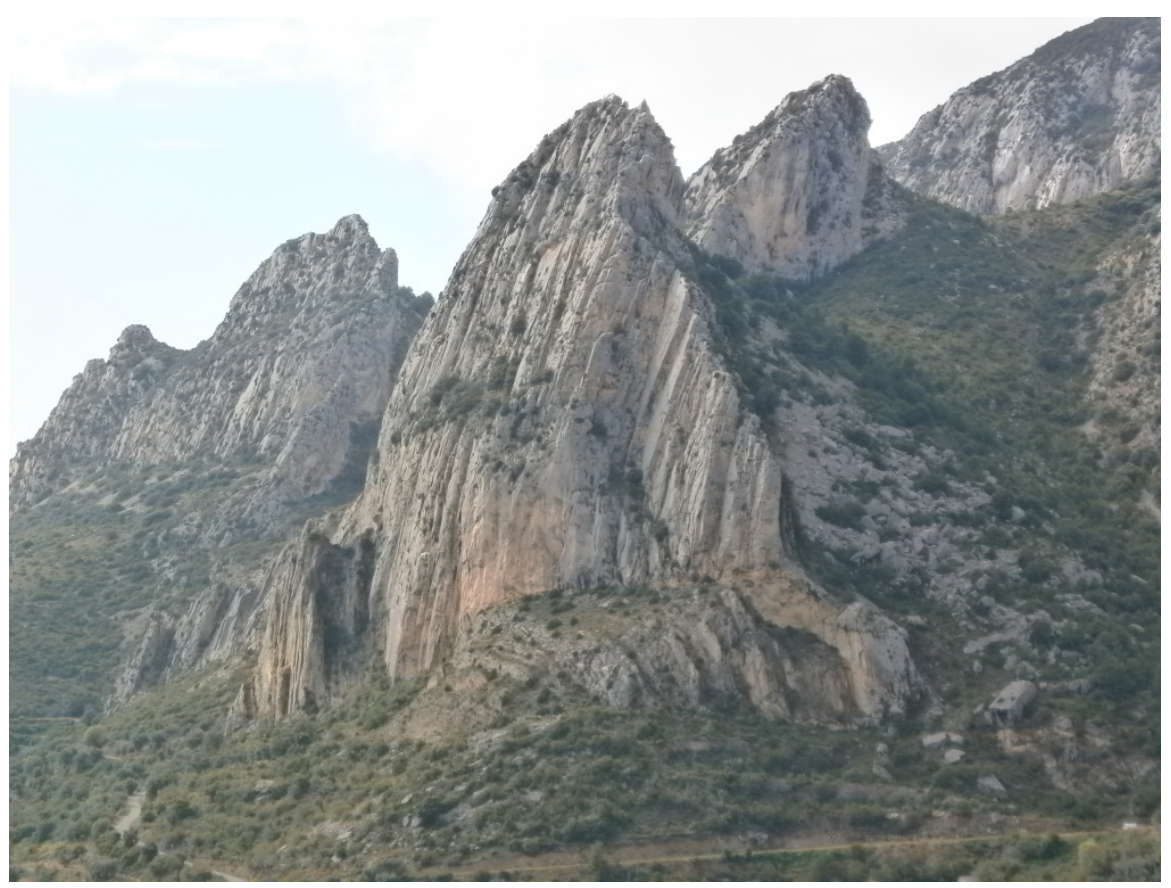

Fotografia 5. Un aspecte del front d'encavalcament del Mantell de Bóixols, des del congost d’Abella de la Conca (lo Foradot), obert pel riu Abella.

Per d'altra banda, des d'aquest indret, situat al bell mig del Congost del riu Abella, es pot veure en detall, com aquests materials cretàcics formen part d'un anticlinal encavalcant, situant-se el seu flanc meridional sobre el mateix poble d'Abella de la Conca, per on encavalquen als terrenys del Garumnià. Es a dir: des d'aquest indret es pot veure be, l'encavalcament del Mantell del Montsec (on hi ha els materials del Garumnià, situat al Sud), per part del Mantell de Bóixols (on hi ha les calcàries cretàciques, situat al Nord). (fotografíes 6 i 7).

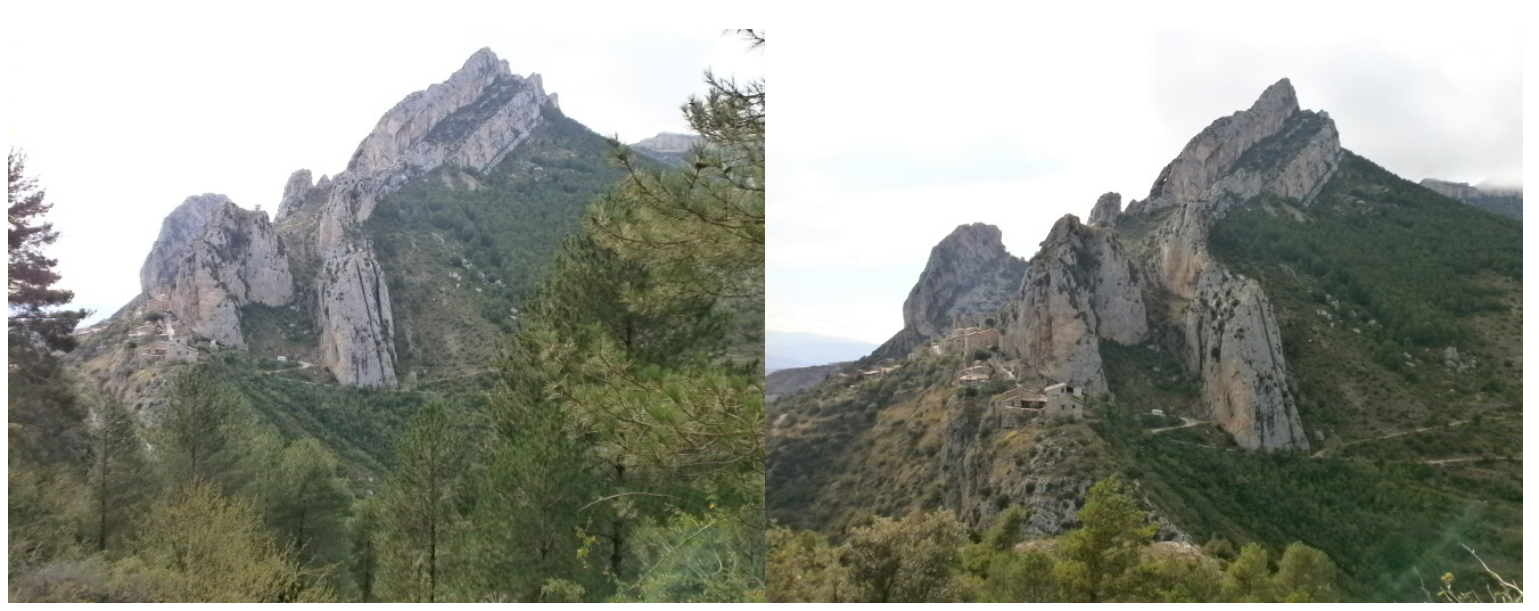

Fotografies 6 i 7. Dos aspectes de l'encavalcament del Mantell de Bóixols, al poble d’Abella de la Conca

Es pot veure be el flanc meridional de I'anticlinal encavalcant Tot, des del camí a Bóixols, al seu pas del Congost del riu Abella. Setembre del 2013 
Per d'altra banda, des d'aquest indret, es pot veure molt clarament el Congost del riu Abella (on estem situats). Ha estat obert per aquest riu, en travessar els materials carbonatats del Mantell de Bòixols. En aquest indret, el riu forma un engorjat, anomenat popularment "lo Foradot". (fotografia 8).

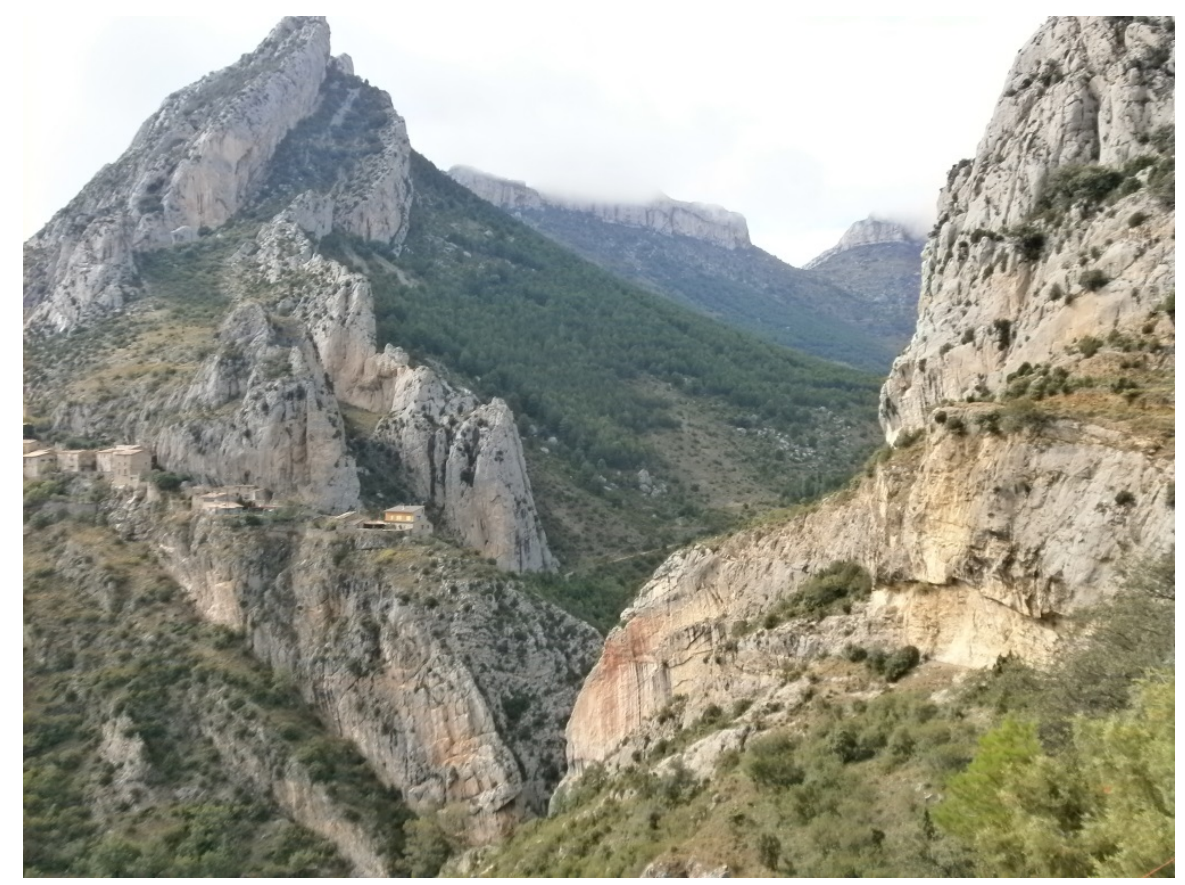

Fotografia 8. Un aspecte del Congost d'Abella de la Conca (lo Foradot), obert pel riu Abella en travessar les calcàries del Mantell de Bòixols. Setembre del 2013 


\subsection{Parada 5. COLLADA DE CARRÀNIMA, (Bóixols, terme municipal d'Abella de la Conca, comarca del Pallars Jussà). (Full 252).}

Després de fer la parada anterior, cal continuar pel camí que condueix cap al poble de Bóixols, tot partint del Congost d'Abella. Aquest camí va ascendint sempre cap el Coll de Carràníma, molt proper ja a la població de Bóixols. En aquest indret, podem fer una nova aturada, a uns 5 $\mathrm{Km}$ de la parada anterior.

En aquest recorregut, haurem anat trobant afloraments dels materials esmentats a l'aturada anterior. Tot i així, ara haurem estat circulant entre materials calcolutitics del Cretàcic Mitjà, dintre del Mantell de Bóixols. On estem ara situats. Aquests materials pertanyen al Santonià. Més amunt, mirant cap el Nord, es poden veure les calcàries del Cretàcic inferior, de l'Aptià, les quals encavalquen als materials que ara estem veient, al Nord del Coll de Carrànima.

Des d'aquest indret, mirant cap al Sud, es pot veure el poble de Bóixols, a tocar de les calcàries de l'Encavalcament de Bòixols, el qual es veu molt be des d'on ara estem situats. (fotografia 9).

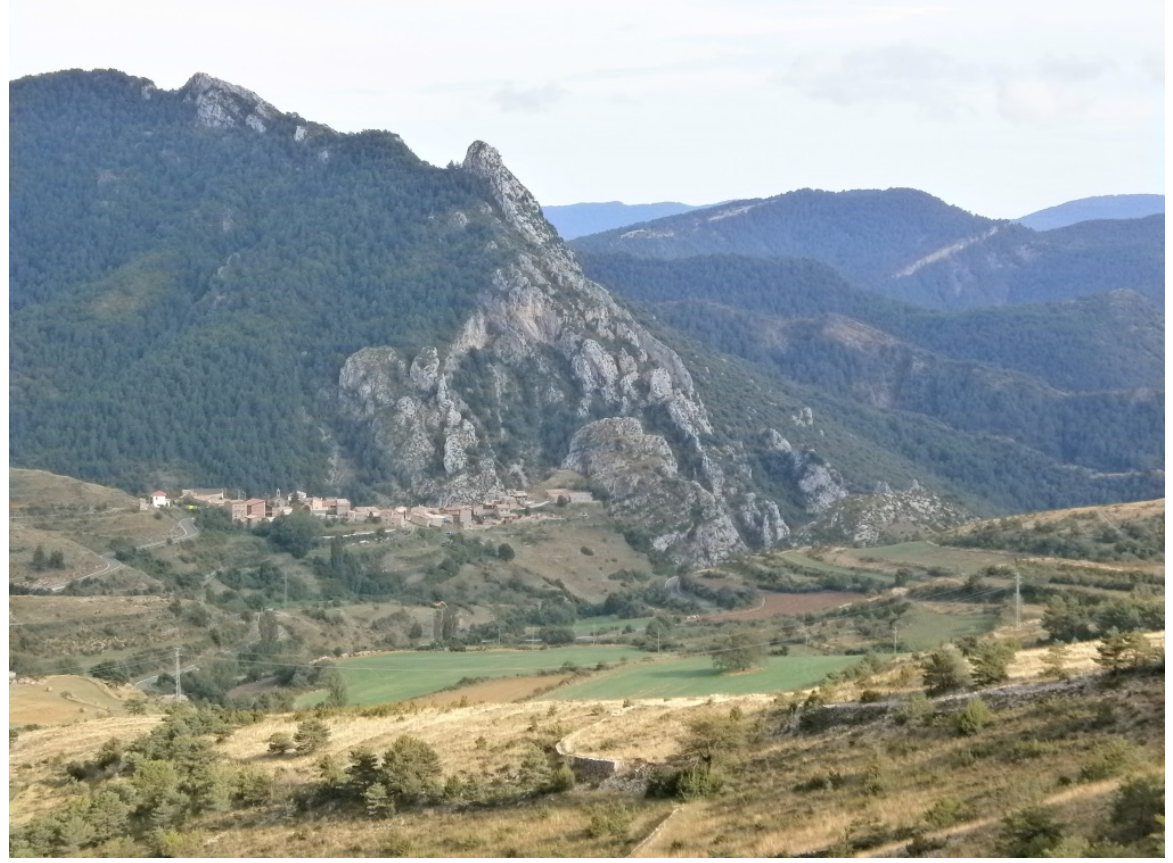

Fotografia 9. Un aspecte del poble de Bòixols, rere l'aflorament de calcàries de Turonià, tot formant part del Mantell de Bòixols. Setembre del 2013 


\subsection{Parada 6. IMMEDIACIONS DE LA CARRETERA L - 511, A 1Km DE BÓIXOLS, ANANT CAP A ISONA, (Bóixols, terme municipal d'Abella de la Conca, comarca del Pallars Jussà). (Full 252).}

Després de fer la parada anterior, cal continuar pel camí que condueix cap al poble de Bóixols, que a partir d'ara es converteix en arribar al poble, caldrà continuar per la carretera local $L$ 511, la qual condueix cap a Isona. Poc després de sobrepassar el poble, prop d'una corba molt pronunciada, caldrà fer una nova aturada, a poc més de $1 \mathrm{Km}$ del poble i a uns $3 \mathrm{Km}$ de la parada anterior.

En aquest tram, haurem trobat afloraments dels materials calcolutítics cretàcics del Sannoisià. Després, prop del poble, haurem vist els afloraments carbonatats cretàcic del Turonià. Tots aquests materials formen part del Mantell de Bóixols, on ens trobem ara situats,.

Des d'aquest indret, es pot gaudir per una part, del congost obert pel riu Rialb (que neix per aquests indrets). També es pot veure l'encavalcament del Mantell de Bóixols sobre els materials del Mantell del Montsec, situat al Sud d'on ara estem situats. (fotografies 10 i 11).

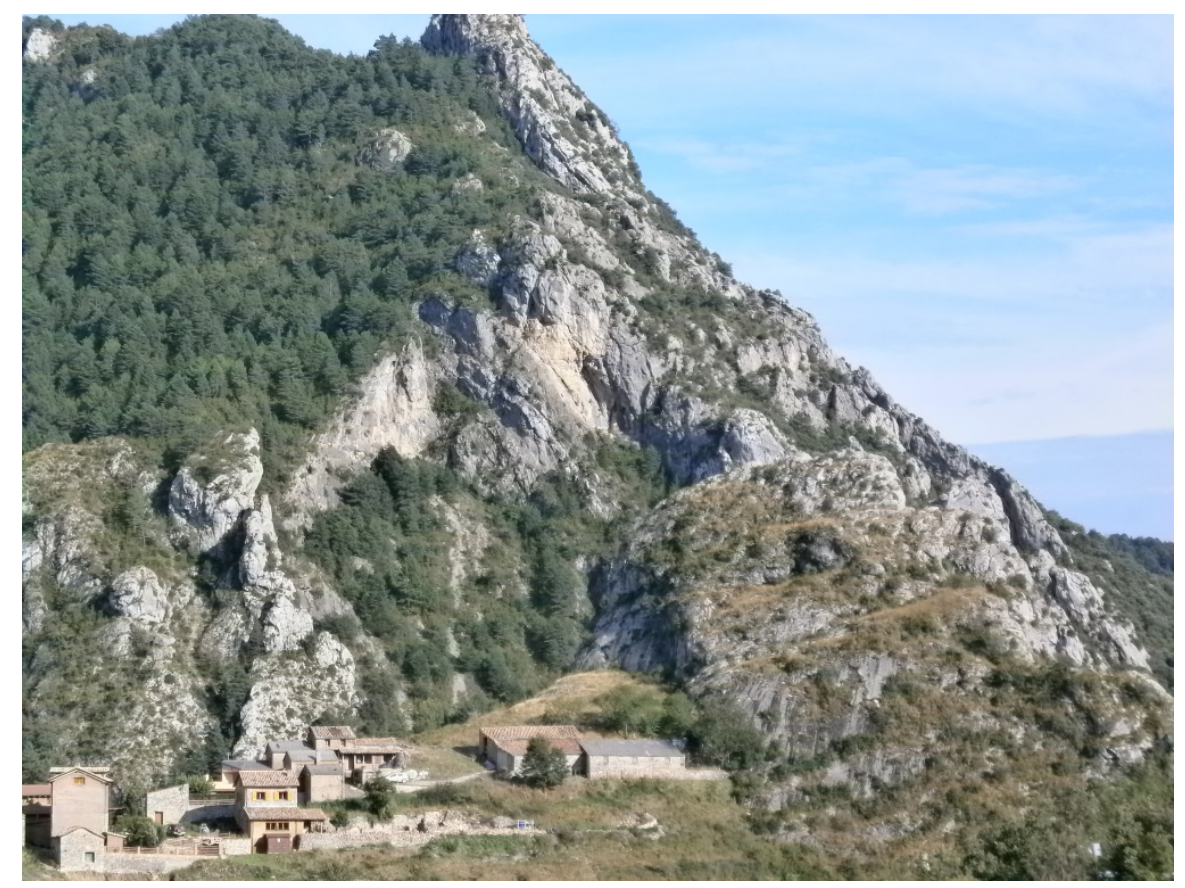

Fotografia 10. Un aspecte del poble de Bòixols, i del Mantell de Bòixols. Setembre del 2013 


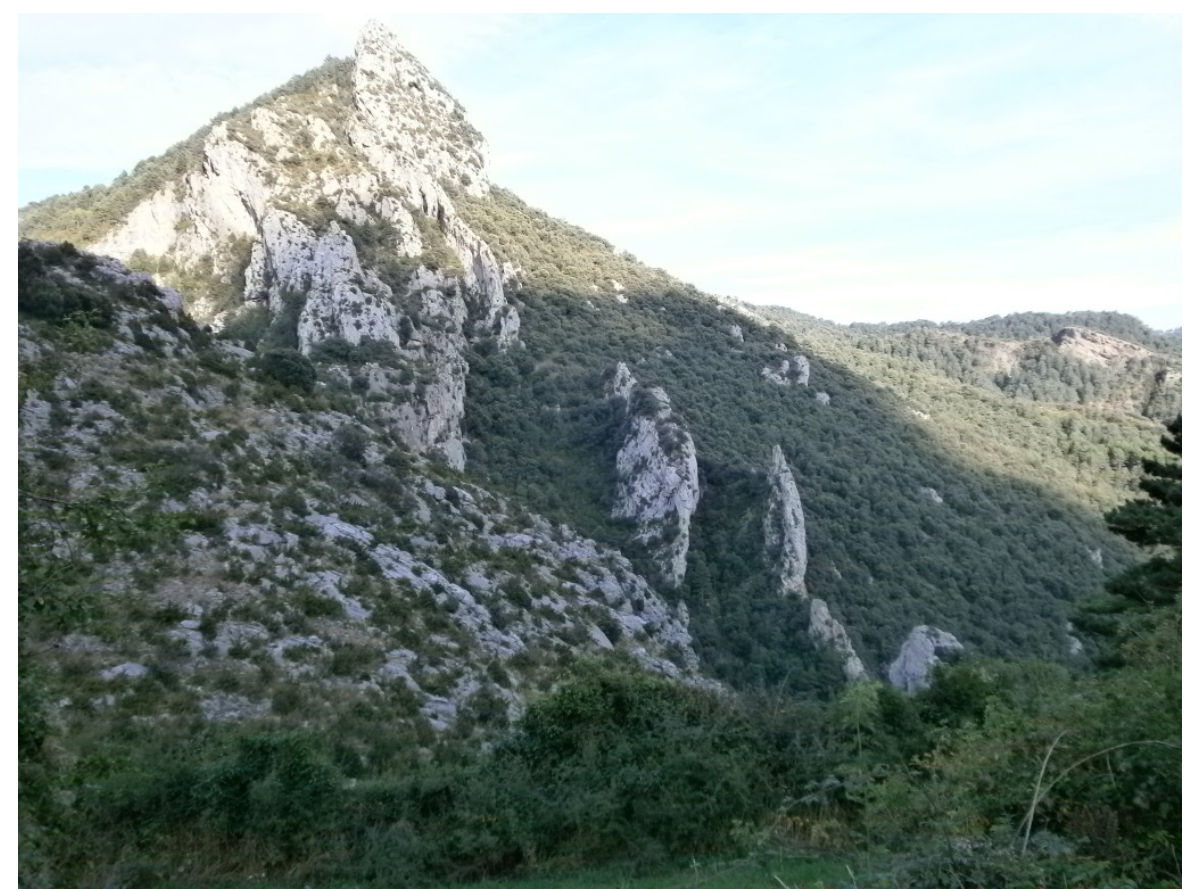

Fotografia 11. Un aspecte del Mantell de Bòixols, encavalcant al Mantell del Montsec. També s'entreveu el Congost obert pel riu Rialb. Setembre del 2013

\subsection{Parada 7.PARC CRETÀCIC DE LA POSA. (Santuari de la Mare de Deu de la Posa, terme municipal d'Isona i la Conca Dellà, comarca del Pallars Jussà). (Full 252).}

Després de fer la parada anterior, cal continuar cap a Isona, per la carretera $L-511$. Després d'un llarg recorregut, d'uns $10 \mathrm{Km}$, en apropar-nos al trencall d'Abella de la Conca, per la dreta, trobarem el trencall del Santuari de la Posa, per l'esquerra. En trobar aquest camí, ens hi caldrà anar. Així, enllà farem la darrera aturada d'aquest itinerari, a uns $11 \mathrm{Km}$ de la darrera aturada, aproximadament. I també a uns $3 \mathrm{Km}$ d’Isona.

En aquest recorregut, haurem travessat l'Encavalcament de Bóixols (a la darrera aturada) i haurem entrat al Mantell del Montsec. Així, haurem vist afloraments eminentment carbonatats i calcolutítics del Cretàcic Superior, fonamentalment del Garumnià, en arribar a l'indret de la present aturada.

En aquest lloc es troba un interessant jaciment d'icnites (de petjades), que inicialment es van atribuir a dinosaures. Posteriorment, s'ha vist que son icnites de rajades. Tot i això, constitueix un altre indret del interessant del nostre Patrimoni Geològic, al marge de les darreres polèmiques sobre la seva autenticitat.

A l'actualitat, en aquest indret s'ha situat el Parc Cretàcic de la Posa. Així, per part del Museu d'Isona, s'ha preparat l'indret per a les visites i es poden observar centenars d'icnites de les esmentades rajades. Aquestes es troben per sota de l'ermita, en una vessant de la Colomera. (fotografia 12). 


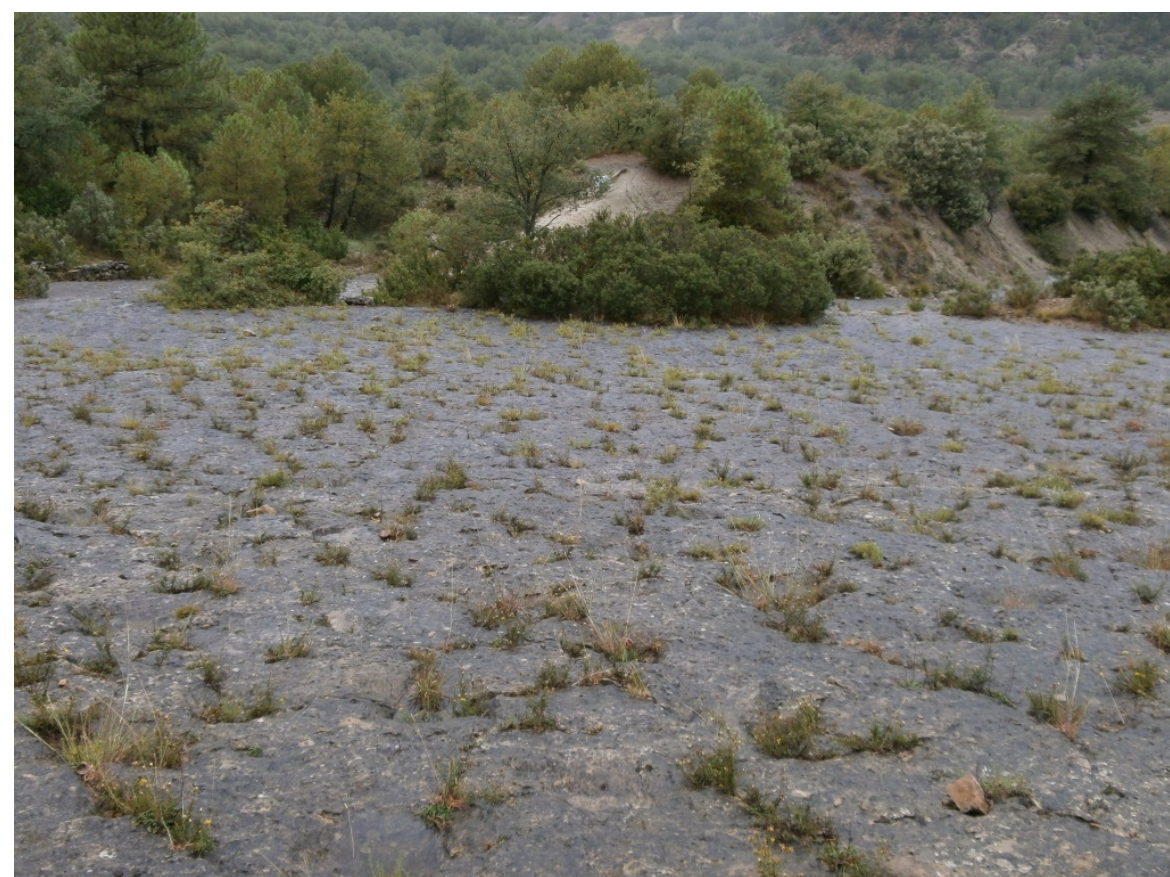

Fotografia 12. Superfície del jaciment d’icnites del Santuari de la Mare de Deu de la Posa. Materials del cretàcic superior del Mantell del Montsec. Setembre del 2013

Per d'altra banda, en aquest indret es poden veure nivellets de lignits, que temps enllà es van intentar d'explotar. Aquests lignits formen part de la Conca Lignitífera d'Isona. Els lignits es situen sobre els afloraments del Garumnià.

En aquest indret finalitza el recorregut de l'itinerari. 


\section{Bibliografia}

GUIMERÀ, J. et altri (1992).- Geologia (II), Història Natural dels Països Catalans, Vol.2, 547 pag. Enciclopèdia Catalana, S.A. Barcelona.

IGME (1970).- Mapa Geológico de España, a escala 1.200.000 (Síntesis de la Cartografia existente). Full i memòria no 24, Berga. Inst. Geol. Minero de España. Madrid.

IGME (1994).- Mapa Geológico de España a escala 1:50.000 (Plan Magna). Fulla i Memòria $n^{\circ}$ 252 (Tremp). Inst. GeoMinero y Tecnol. España. Minist. Indústria. Madrid.

MATA - PERELlÓ, J.M. (1991).- Els Minerals de Catalunya. Arxius de la Secció de Ciències, t. XCIII, 442 pag. Institut d’Estudis Catalans. Barcelona.

MATA-PERELLÓ, J.M. (1995).- Itinerari Geològico-Mineralògic pel Pallars Jussà i pel Pallars Sobirà: des de Puimanyons a Sort. Inèdit, 13 pàgines. Barcelona.

MATA - PERELLÓ, J.M. (1996a).- Itinerari geològico-mineralògic per la comarca de la Noguera. des de Montclar d’Urgell a la Foradada, Inèdit. 12 pag. Manresa.

MATA - PERELLÓ, J.M. (1996b).- Itinerari geològico-mineralògic per la Noguera: des de Bellmunt d’Urgell a Vilanova de la Sal, Inèdit, 13pag. Manresa.

MATA - PERELLÓ, J.M. (1996c).- Itinerari geològico-mineralògic per la Noguera: des Montclar d’Urgell a Santa Maria de Meià, Inèdit, 13pag. Manresa.

MATA-PERELLÓ, J.M. (1996d).- Recerca geològica i mineralògica pels dos Pallars: des del pas de Terradets al Pas de Collegats, per Tremp i per Gerri de la Sal. Inèdit. 12 pàgines. Manresa.

MATA-PERELLÓ, J.M. (1999).- Recerca geològica i mineralògica per les comarques de la Noguera i del Pallars Jussà: des del Pont d'Alentorn a Vilanova de Meià, i des del Pas Nou al congost d’Erinyà. Revista Algeps, nº 87, 10 pag. Manresa.

MATA-PERELLÓ, J.M. (2002a).- Recerca geològica i mineralògica per la comarca del Pallars Jussà: des del Port de Comiols a Llimiana i a Tremp. Revista Xaragall, sèrie $B, n^{\circ}$ 194, 8 pag. Manresa.

MATA-PERELLÓ, J.M. (2002b).- Recerca geològica i mineralògica per les comarques del Pallars Jussà i de l'Alta Ribagorça: des de la Pobla de Segur a Xerallo i al Pont de Suert. Revista Xaragall, sèrie $B, \mathrm{n}^{\circ}$ 195, 12 pag. Manresa.

MATA-PERELLÓ, J.M. (2009).- Recorregut de recerca geològica i mineralògica per la comarca del Pallars Jussà: des de la Pobla de Segur a Tremp i a Isona, tot passant per Basturs, Suterranya i Abella. Inèdit. 8 pàgines. Manresa.

MATA-PERELLÓ, J.M. (2013).- Recorregut de recerca geològica i mineralògica per la comarca del Pallars Jussà: des d'Erinyà a la Pobla de Segur, a Tremp i a Isona, tot passant per Figuerola d'Orcau, Basturs i Abella de la Conca. Inèdit. 12 pàgines. Manresa.

MATA-PERELLÓ, J.M. i MONTANÉ GARCÍA, P. (2002).- Recorregut de recerca geològica i mineralògica per les comarques del Pallars Jussà i del Pallars Sobirà: des de la Font de les Bagasses a l'Estany de Montcortès, tot passant per Basturs. Inèdit. 12 pag. Manresa.

MATA-PERELLÓ, J.M. i MONTANÉ GARCÍA, P. (2005a).- Recorregut de recerca geològica i mineralògica per les terres dels dos Pallars: des de la Pobla de Segur i Sossís cap a la Torre de Cabdella i a Gerri de la Sal. Inèdit 8 pag. Manresa. 
MATA-PERELLÓ, J.M. i MONTANÉ GARCÍA, P. (2005b).- Recorregut de recerca geològica i mineralògica per la comarca del Pallars Jussà: des de la pobla de Segur a Tremp i a Isona, tot passant per les immediacions de Basturs, de Suterranya i de Bóixols. Inèdit. 8 pag, Manresa.

MATA-PERELLÓ, J.M. i MONTANÉ GARCÍA, P. (2006).- Recorregut de recerca geològica i mineralògica per la comarca del Pallars Jussà: des de la Pobla de Segur i les Mines de Sossís cap a Tremp i a Isona, tot passant per Basturs, Suterranya, Abella i la Posa. Inèdit. 10pag. Manresa.

RIBA, O. et altri (1976).- Geografia Física dels Països Catalans, Edit. Ketres, 254 pàgines. Barcelona.

ROSELL SANUI, J. (1970).- Explicació del Mapa Geològic, a escala 1:50.000, corresponent al full n 252 (Tremp). Mapa Geológico de España. Inst. Geológico y Minero de España. Madrid. 